\title{
The Effects of the Students' Hierarchy of Needs in an Indonesian Private Academy on the Intention to Buy in Social Commerce
}

\author{
Fatimah Muthmainnah ${ }^{1 *}$ and Fergyanto E. Gunawan ${ }^{2}$ \\ ${ }^{1}$ Information Systems Management Department, BINUS Graduate Program - Master Information \\ Systems Management, Bina Nusantara University \\ ${ }^{2}$ Industrial Engineering Department, BINUS Graduate Program - Master of Industrial Engineering, \\ Bina Nusantara University \\ Jakarta 11480, Indonesia \\ Email: ${ }^{1}$ fatimah.muthmainnah@binus.ac.id, ${ }^{2}$ fgunawan@binus.edu
}

\begin{abstract}
In line with Internet users' growth in Indonesia, many people buy and sell goods and services through social networking sites. This activity is social commerce, and it primarily affects the millennials, such as private academy students. The research is conducted to determine the effects of the hierarchy of needs in a private academy in Indonesia on students' intentions to buy in social commerce. Facebook, Instagram, and Whatsapp are the used social commerce in the research. The questionnaire is answered by 126 respondents consisting of indicators from Maslow's hierarchical needs. The analysis technique is Partial Least Square (PLS) with the SmartPLS 3.0 program. Hypothesis test results show that transcendence, self-actualization, cognitive needs, and physiological needs have no significant effect on the intention to buy in social commerce. Meanwhile, esteem needs, safety needs, aesthetic needs, and belonging and love needs affect intention to buy.
\end{abstract}

Index Terms-Hierarchy of Needs, Intention to Buy, Social Commerce

\section{INTRODUCTION}

I NTERNET users in Indonesia grow vastly. According to a survey by the Asosiasi Penyelenggara Jasa Internet Indonesia 'Indonesian Internet Service Providers Association' (APJII) in 2018, the Internet users in Indonesia had reached 171.17 million [1]. Many Internet users, merchants, and Small and Medium Enterprises (SMEs) sell their products on social media. The results of PayPal survey in 2017 involving 4.000 consumers and 1.400 SMEs in Asia (China, India, Hong Kong, Singapore, Thailand, the Philippines, and Indonesia) showed $92 \%$ of merchants in Indonesia used Facebook [2].

Received: Aug. 24, 2020; received in revised form: Oct. 20, 2020; accepted: Oct. 20, 2020; available online: Nov. 04, 2020. *Corresponding Author
Social commerce is a part of electronic commerce (e-commerce). In particular, it is a combination of e-commerce, e-marketing, assistive technology, and social media content. It is made from the integration of e-commerce and e-marketing using Web 2.0 or social media applications [3]. Thus, the activities are carried out on social networks. It refers to the sale and purchase of goods and services through social media such as Facebook, Instagram, and WhatsApp [4]. It also uses social media to expand e-commerce. It summarizes various technologies and aspects [5].

In addition to these data, the great potential of the e-commerce industry in Indonesia is also influenced by online shopping styles, especially by the millennials [6]. Millennials are the generation born between 1981-2000 [7]. According to data from the Central Statistics Agency (BPS), Indonesia's population aged 20 to 40 years in 2020 is estimated to be 83 million people or $34 \%$ of Indonesia's total population of 271 million [8]. One of the characteristics of the urban middle-class millennials is connected. The presence of the Internet bridges this characteristic. The millennials grow together with the development of the Internet. For the millennials, it has become a basic necessity. Following Maslow's theory, now the Internet has entered the basic pyramid along with clothes, food, and shelter [9].

Previous researchers examine millennials on social commerce by explaining how social identity affects social commerce. The research summarizes data from a three-year longitudinal study of millennials using social media across three platforms: Facebook, Twitter, and Pinterest. The results show that millennials prefer to take advantage of the identity-forming aspects of 
Cite this article as: F. Muthmainnah and F. E. Gunawan, "The Effects of the Students' Hierarchy of Needs in an Indonesian Private Academy on the Intention to Buy in Social Commerce", CommIT (Communication \& Information Technology) Journal 14(2), 81-88, 2020.

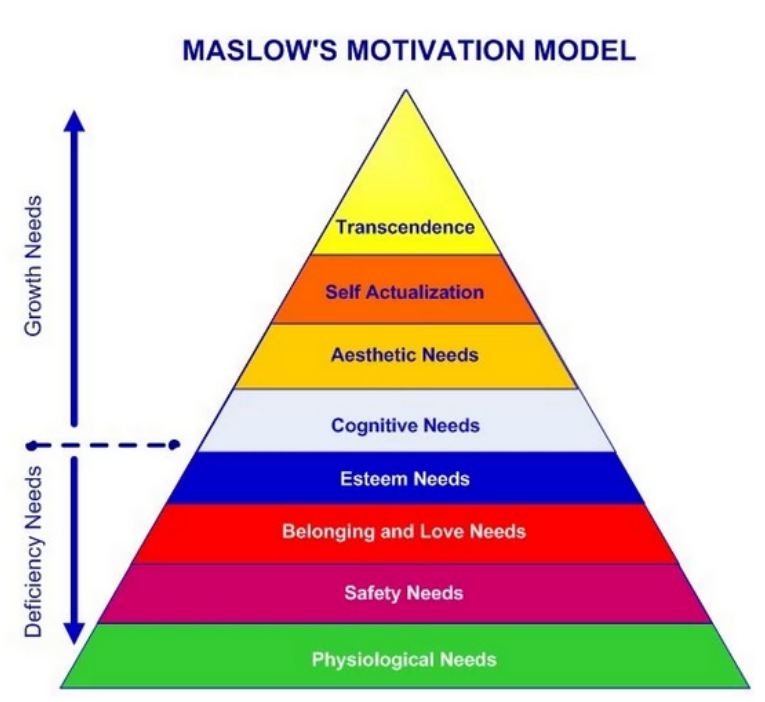

Fig. 1. Maslow's hierarchy of needs [16].

social media and trading [10]. There is also research regarding millennials' acceptance of social commerce as measured through the Unified Theory of Acceptance and Use of Technology (UTAUT). This research integrates several factors contained in the UTAUT model. The data obtained are from a survey of 100 respondents. The research uses descriptive statistics and Pearson correlation. Based on the analysis, there is a significant relationship between gender and age with the factors that affect the acceptance of the social commerce of students at State Universities in the Philippines. The research analyzes the relationship between social commerce constructs and consumer intentions to buy. In conclusion, consumers use social trading constructs for this activity, which in turn increases levels of trust and purchase intention [11].

However, from previous research, there are not many studies related to the effects of the hierarchy of needs on the intention to buy in social commerce. Maslow's five-stage models of 1943 [12] and 1954 [13] have been expanded to include cognitive and aesthetic needs [14] as well as transcendent needs [15]. The change to the five stages of the original model is highlighted. It consists of eight stages. The stages in Maslow's hierarchy of needs can be seen in Fig. 1 .

The eight stages consist of pyramid-shaped need levels. It means that the most basic needs must be met before fulfilling the above needs. The eight stages are divided into two groups of needs: growth needs (the need to meet development) and deficiency needs (the need to meet deficiencies). In growth needs, there are transcendence, self-actualization, aesthetic needs, and cognitive needs. Meanwhile, deficiency needs include esteem needs, belonging and love needs, safety needs, and physiological needs [16].

First, physiological needs are the basics that must be met before other needs. In social commerce, the basic needs are the functional requirements of the system. Functional requirements are all necessary components on social media for consumers to complete a purchase. Second, safety needs refer to the security in commerce on social media. Third, in social commerce, belonging and love needs mean social relations between consumers and sellers. Fourth, esteem needs are the desire to increase the dignity and self-respect as well as the reputation or recognition of others. Fifth, cognitive needs refer to exploratory experience in commerce on social media. Sixth, aesthetic needs is the requirement for aesthetics or beauty offered in commerce on social media. Seventh, self-actualization means the need for self-development, self-fulfillment, and peak experiences. Last, transcendence refers to the need to help others and put the interests of others first.

Based on the explanation, the hypotheses in the research are:

H1: There is an effect of transcendence on the intention to buy in social commerce

$\mathrm{H} 2$ : There is an effect of self-actualization on the intention to buy in social commerce

H3: There is an effect of aesthetic needs on the intention to buy in social commerce

H4: There is an effect of cognitive needs on the intention to buy in social commerce

H5: There is an effect of esteem needs on the intention to buy in social commerce

H6: There is an effect of belonging and love needs on the intention to buy in social commerce

H7: There is an effect of safety needs on the intention to buy in social commerce

H8: There is an effect of physiological needs on the intention to buy in social commerce

The concept of the hierarchy of needs by Maslow will measure the users' experience in social commerce by analyzing what factors have not been met and have been met in social commerce. The fulfilled and unfulfilled needs of consumers will affect the intention to buy in social commerce. The researcher will analyze the effects of the hierarchy of needs of students in a private academy in Indonesia on their intentions to buy in social commerce and examine the research models from previous studies related to the intention to buy. Hence, the models in the research have been tested in previous studies.

\section{RESEARCH METHOD}

The used method is quantitative research with the theory from previous studies. The research looks for 
Cite this article as: F. Muthmainnah and F. E. Gunawan, "The Effects of the Students' Hierarchy of Needs in an Indonesian Private Academy on the Intention to Buy in Social Commerce", CommIT (Communication \& Information Technology) Journal 14(2), 81-88, 2020.

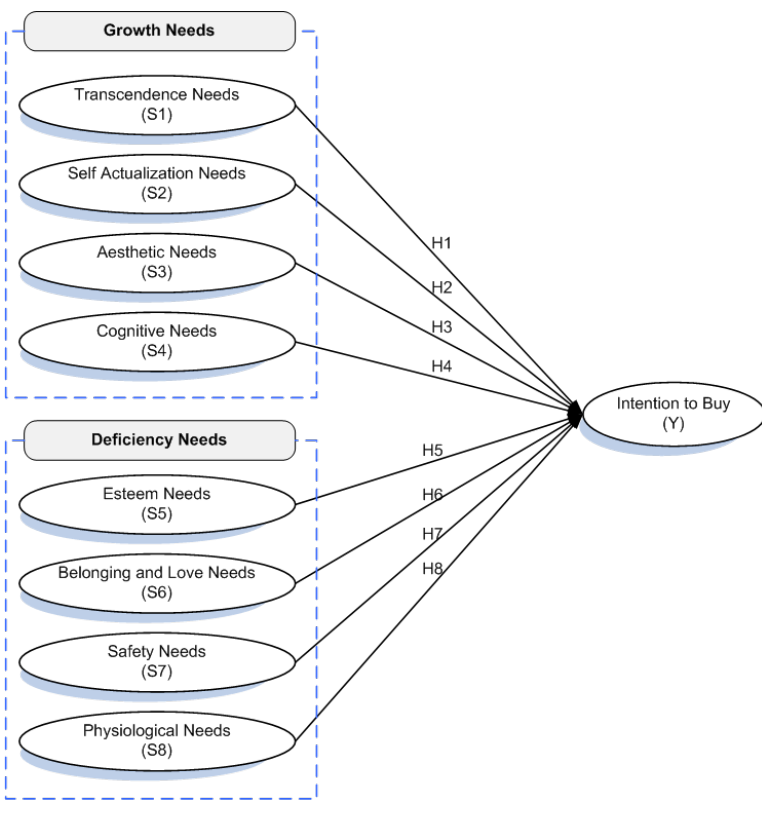

Fig. 2. Research framework.

a causal relationship between the independent and dependent variables. The research uses a research model on social commerce from several literature studies from national and international journals. Those become the basis for making research models by combining models from previous related studies. At the data collection stage, the researchers use two methods: literature study and survey. Literature studies are carried out by searching for data through journals, books, articles, and the Internet related to purchase intentions. Then, the researchers analyze the influencing variables and the appropriate model for purchase intention in previous research.

The survey is conducted by distributing questionnaires to a predetermined sample using a nonprobability sample selection method with purposive sampling [17]. The research sample is the millennial generation between $20-40$ years in 2020 from a private academy in Indonesia. The limitation of the questionnaire is that the researchers only use three social media in Indonesia. Those are often used as media for online buying and selling, namely Facebook, Instagram, and Whatsapp. The questionnaire is distributed online to 126 respondents from a private academy in Indonesia.

The indicators from Maslow's hierarchical needs model can assess and influence consumers' affective and cognitive evaluations. The intention to buy social commerce is used for describing the reaction to consumers' behavior. The hypothesis test uses the Partial Least Square (PLS) analysis technique with the SmartPLS 3.0. The research model can be seen
TABLE I

DEMOGRAPHICS OF RESPONDENTS.

\begin{tabular}{lcrr}
\hline & & Respondents & $\%$ \\
\hline \multirow{2}{*}{ Gender } & Male & 45 & 36 \\
& Female & 81 & 64 \\
\hline Age & $20-40$ years & 126 & 100 \\
\hline \multirow{3}{*}{ Duration of Using } & 1-5 hour & 5 & 4 \\
Social Media & 6-9 hours & 56 & 44 \\
& $>9$ hours & 29 & 23 \\
& Facebook & 18 & 29 \\
Types of Social & Instagram & 59 & 14 \\
Commerce & Whatsapp & 49 & 39 \\
\hline Usage of Social & Facebook & 10 & 22 \\
Commerce based & Instagram & 19 & 42 \\
on gender (Male) & Whatsapp & 16 & 36 \\
\hline Usage of Social & Facebook & 8 & 10 \\
Commerce based & Instagram & 40 & 49 \\
on gender (Female) & Whatsapp & 33 & 41 \\
\hline
\end{tabular}

in Fig. 2.

\section{RESUlts AND Discussion}

Table I presents the demographic data of the respondents. Based on gender, there are more female than male respondents. The male respondents are $36 \%$ or 45 people. Meanwhile, the rest is female, with $64 \%$ or 81 people. So, it can be concluded that female respondents access social media and make online purchases more than male respondents. Based on age, all respondents (100\% or 126 people) are millennials. They are 20 to 40 years olds. Moreover, according to social media usage per day, many respondents use it 1 to 5 hours (44\% or 56 people). The result is followed more than 9 hours (29\% or 36 people), 6 to 9 hours (23\% or 29 people), and under 1 hour ( $4 \%$ or 5 people). It shows that each respondent uses the most social media between 1 and 5 hours a day.

From 126 respondents, more respondents choose Instagram as social commerce, which they often access and make transactions. About 59 people (47\%) choose Instagram. It is followed by WhatsApp (39\% or 49 people). Then, Facebook is the least visited and used by respondents, with a percentage of only $1 \%$ as many as 18 people. Then, the results are divided based on gender. It can see the social commerce that is most frequently accessed and used by the male and female respondents. From Table 1, it can be seen that 19 out of 45 male respondents $(42 \%)$ access and use Instagram while the number is slightly higher for female respondents (40 of 81 people or $49 \%$ ). According to this result, sellers in the future can focus more on selling more goods or accessories directed at millennials on Instagram. It is because Instagram is the most popular social media. 
Cite this article as: F. Muthmainnah and F. E. Gunawan, "The Effects of the Students' Hierarchy of Needs in an Indonesian Private Academy on the Intention to Buy in Social Commerce", CommIT (Communication \& Information Technology) Journal 14(2), 81-88, 2020.

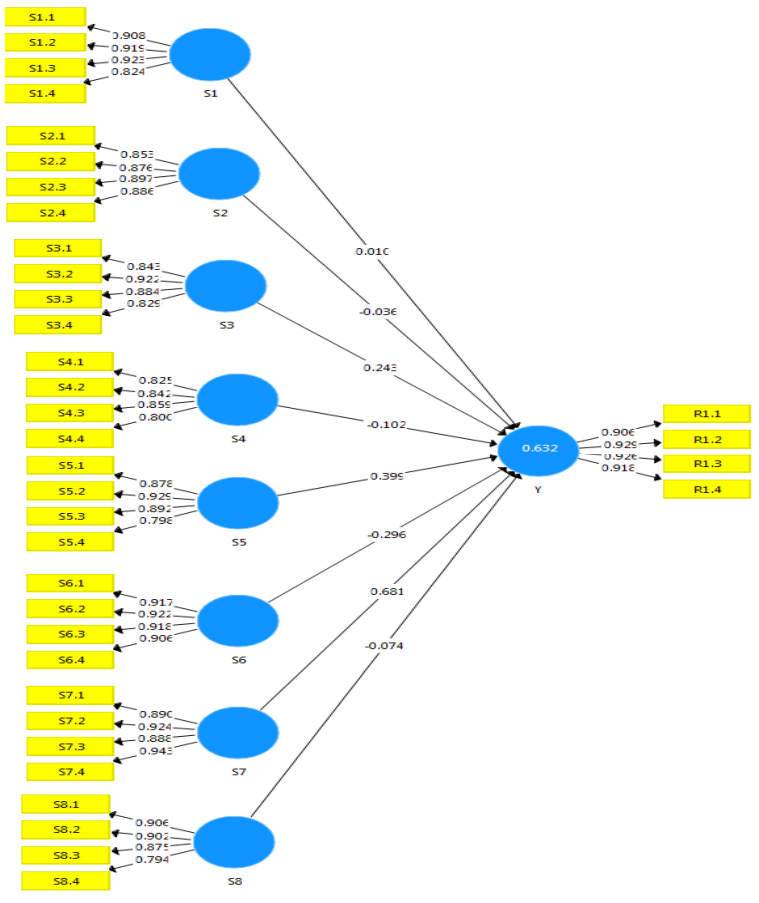

Fig. 3. Outer and inner models.

Next, the tests are divided into outer and inner models. Figure 3 shows a schematic of the PLS program model that will be tested. The first outer model evaluation is convergent validity. The discriminant validity assessment aims to ensure that a reflective construct has the strongest relationships with its indicators (e.g., in comparison with other constructs) in the PLS path model [18]. To test the convergent validity, the researchers use the outer loading or loading factor value. The outer loading value between 0.5 and 0.6 is considered sufficient to meet the requirements $[19,20]$. Moreover, an indicator is declared to meet the convergent validity in the good category if the outer loading value is $>0.7$. Table II shows the outer loading value of each indicator in the research variable. Each indicator of the variables has an outer loading value of $>0.7$. The data shows that there is no variable indicator with below 0.5 outer loading value. Hence, all indicators are declared valid and can be used for further analysis.

Next, it is the discriminant validity test. Discriminant validity is demonstrated by evidence that measures the constructs. Theoretically, it should not be highly related to each other and is not found to be correlated with each other. Practically speaking, discriminant validity coefficients should be noticeably smaller in magnitude than convergent validity coefficients [21]. The crossloading value of each indicator is shown in Table III.
TABLE II

OUTER LOADING OF THE INDICATORS.

\begin{tabular}{|c|c|c|}
\hline Variable & Indicator & Outer Loading \\
\hline \multirow{4}{*}{ Intention to buy (R1) } & $\mathrm{R} 1.1$ & 0.906 \\
\hline & $\mathrm{R} 1.2$ & 0.929 \\
\hline & $\mathrm{R} 1.3$ & 0.926 \\
\hline & R1.4 & 0.918 \\
\hline \multirow{4}{*}{ Transcendence (S1) } & $\mathrm{S} 1.1$ & 0.908 \\
\hline & $\mathrm{S} 1.2$ & 0.919 \\
\hline & $\mathrm{S} 1.3$ & 0.923 \\
\hline & $\mathrm{S} 1.4$ & 0.824 \\
\hline \multirow{4}{*}{ Self-actualization (S2) } & S2.1 & 0.853 \\
\hline & S2.2 & 0.876 \\
\hline & S2.3 & 0.897 \\
\hline & $\mathrm{S} 2.4$ & 0.886 \\
\hline \multirow{4}{*}{ Aesthetic needs (S3) } & S 3.1 & 0.843 \\
\hline & S 3.2 & 0.922 \\
\hline & S 3.3 & 0.884 \\
\hline & S 3.4 & 0.829 \\
\hline \multirow{4}{*}{ Cognitive needs (S4) } & S4.1 & 0.825 \\
\hline & S4.2 & 0.842 \\
\hline & S4.3 & 0.859 \\
\hline & S4.4 & 0.800 \\
\hline \multirow{4}{*}{ Esteem needs (S5) } & S5.1 & 0.878 \\
\hline & S5.2 & 0.929 \\
\hline & S5.3 & 0.892 \\
\hline & S5.4 & 0.798 \\
\hline \multirow{4}{*}{ Belonging and love needs (S6) } & S6.1 & 0.917 \\
\hline & S6.2 & 0.922 \\
\hline & S6.3 & 0.918 \\
\hline & S6.4 & 0.906 \\
\hline \multirow{4}{*}{ Safety needs (S7) } & S7.1 & 0.890 \\
\hline & S7.2 & 0.924 \\
\hline & S7.3 & 0.888 \\
\hline & S7.4 & 0.943 \\
\hline \multirow{4}{*}{ Physiological needs (S8) } & S8.1 & 0.906 \\
\hline & S8.2 & 0.902 \\
\hline & S8.3 & 0.875 \\
\hline & S8.4 & 0.794 \\
\hline
\end{tabular}

Based on Table III, each indicator in the research variable has the largest cross-loading value compared to other variables. Based on the results obtained, the used indicators have good discriminant validity in compiling their respective variables. In addition to observing the cross-loading value, discriminant validity can also be determined through other methods. It is done by looking at the Average Variant Extracted (AVE) value for each indicator. It requires the value to be $>0.5$ for a good model [20]. Table IV shows that the AVE value of all variables is $>0.5$. Thus, it can be stated that each variable has good discriminant validity.

Composite reliability is used to test the reliability value of indicators. A variable is reliable if it has a composite reliability value of $>0.6$ [20]. The composite reliability value of each used variable is shown in Table V. It can be seen that the composite reliability value of all research variables is $>0.6$. These results indicate that each variable has met the requirement, so 
Cite this article as: F. Muthmainnah and F. E. Gunawan, "The Effects of the Students' Hierarchy of Needs in an Indonesian Private Academy on the Intention to Buy in Social Commerce", CommIT (Communication \& Information Technology) Journal 14(2), 81-88, 2020.

TABLE III

CROSS-LOADING VALUES OF THE INDICATORS.

\begin{tabular}{|c|c|c|c|c|c|c|c|c|c|}
\hline Indicator/Variable & $\mathrm{R} 1$ & S1 & $\mathrm{S} 2$ & S3 & S4 & S5 & S6 & S7 & S8 \\
\hline $\mathrm{R} 1.1$ & 0.312 & 0.521 & 0.413 & 0.484 & 0.592 & 0.423 & 0.693 & 0.525 & 0.906 \\
\hline R1.2 & 0.353 & 0.604 & 0.518 & 0.509 & 0.657 & 0.514 & 0.697 & 0.499 & 0.929 \\
\hline R1.3 & 0.359 & 0.549 & 0.470 & 0.455 & 0.620 & 0.479 & 0.636 & 0.494 & 0.926 \\
\hline R1.4 & 0.349 & 0.495 & 0.415 & 0.473 & 0.567 & 0.465 & 0.738 & 0.589 & 0.918 \\
\hline S1.1 & 0.908 & 0.473 & 0.671 & 0.457 & 0.462 & 0.636 & 0.432 & 0.473 & 0.363 \\
\hline S1.2 & 0.919 & 0.419 & 0.614 & 0.427 & 0.471 & 0.620 & 0.365 & 0.422 & 0.321 \\
\hline S1.3 & 0.923 & 0.468 & 0.634 & 0.418 & 0.458 & 0.659 & 0.413 & 0.447 & 0.343 \\
\hline S1.4 & 0.824 & 0.393 & 0.628 & 0.388 & 0.369 & 0.591 & 0.383 & 0.474 & 0.301 \\
\hline S2.1 & 0.485 & 0.853 & 0.556 & 0.615 & 0.628 & 0.602 & 0.578 & 0.511 & 0.505 \\
\hline S2.2 & 0.479 & 0.876 & 0.611 & 0.648 & 0.669 & 0.559 & 0.582 & 0.575 & 0.526 \\
\hline S2.3 & 0.437 & 0.897 & 0.556 & 0.648 & 0.715 & 0.548 & 0.575 & 0.484 & 0.469 \\
\hline S2.4 & 0.336 & 0.886 & 0.493 & 0.724 & 0.759 & 0.557 & 0.654 & 0.531 & 0.561 \\
\hline S3.1 & 0.654 & 0.549 & 0.843 & 0.631 & 0.519 & 0.695 & 0.504 & 0.581 & 0.451 \\
\hline S3.2 & 0.662 & 0.534 & 0.922 & 0.508 & 0.427 & 0.624 & 0.455 & 0.528 & 0.402 \\
\hline S3.3 & 0.638 & 0.527 & 0.884 & 0.573 & 0.497 & 0.669 & 0.466 & 0.549 & 0.430 \\
\hline S3.4 & 0.521 & 0.575 & 0.829 & 0.592 & 0.527 & 0.663 & 0.510 & 0.511 & 0.429 \\
\hline S4.1 & 0.339 & 0.564 & 0.519 & 0.825 & 0.533 & 0.549 & 0.444 & 0.422 & 0.363 \\
\hline S4.2 & 0.456 & 0.649 & 0.590 & 0.842 & 0.620 & 0.665 & 0.572 & 0.519 & 0.472 \\
\hline S4.3 & 0.366 & 0.568 & 0.563 & 0.859 & 0.608 & 0.635 & 0.522 & 0.560 & 0.416 \\
\hline S4.4 & 0.397 & 0.700 & 0.534 & 0.800 & 0.740 & 0.571 & 0.610 & 0.564 & 0.468 \\
\hline S5.1 & 0.498 & 0.647 & 0.532 & 0.653 & 0.878 & 0.675 & 0.618 & 0.609 & 0.620 \\
\hline S5.2 & 0.487 & 0.738 & 0.531 & 0.688 & 0.929 & 0.709 & 0.681 & 0.591 & 0.613 \\
\hline S5.3 & 0.365 & 0.710 & 0.428 & 0.683 & 0.892 & 0.570 & 0.625 & 0.535 & 0.558 \\
\hline S5.4 & 0.367 & 0.678 & 0.497 & 0.639 & 0.798 & 0.571 & 0.586 & 0.526 & 0.519 \\
\hline S6.1 & 0.561 & 0.574 & 0.644 & 0.650 & 0.707 & 0.917 & 0.678 & 0.673 & 0.523 \\
\hline S6.2 & 0.620 & 0.617 & 0.700 & 0.678 & 0.670 & 0.922 & 0.649 & 0.615 & 0.451 \\
\hline S6.3 & 0.670 & 0.589 & 0.729 & 0.673 & 0.632 & 0.918 & 0.605 & 0.654 & 0.428 \\
\hline S6.4 & 0.728 & 0.586 & 0.737 & 0.680 & 0.636 & 0.906 & 0.620 & 0.660 & 0.460 \\
\hline S7.1 & 0.377 & 0.615 & 0.521 & 0.562 & 0.621 & 0.620 & 0.890 & 0.670 & 0.670 \\
\hline S7.2 & 0.351 & 0.667 & 0.447 & 0.589 & 0.698 & 0.579 & 0.924 & 0.687 & 0.728 \\
\hline S7.3 & 0.458 & 0.628 & 0.544 & 0.623 & 0.640 & 0.683 & 0.888 & 0.707 & 0.654 \\
\hline S7.4 & 0.448 & 0.577 & 0.530 & 0.610 & 0.654 & 0.673 & 0.943 & 0.763 & 0.686 \\
\hline S8.1 & 0.383 & 0.607 & 0.513 & 0.618 & 0.657 & 0.645 & 0.772 & 0.906 & 0.587 \\
\hline S8.2 & 0.578 & 0.575 & 0.636 & 0.614 & 0.584 & 0.655 & 0.696 & 0.902 & 0.552 \\
\hline S8.3 & 0.407 & 0.478 & 0.582 & 0.506 & 0.478 & 0.611 & 0.614 & 0.875 & 0.418 \\
\hline S8.4 & 0.386 & 0.382 & 0.437 & 0.398 & 0.500 & 0.558 & 0.583 & 0.794 & 0.390 \\
\hline
\end{tabular}

TABLE IV

The AVerage Variant EXtracted Values of the VARIABLES.

\begin{tabular}{cc}
\hline Variable & AVE \\
\hline Intention to buy (R1) & 0.847 \\
Transcendence (S1) & 0.800 \\
Self-actualization (S2) & 0.771 \\
Aesthetic needs (S3) & 0.757 \\
Cognitive needs (S4) & 0.692 \\
Esteem needs (S5) & 0.767 \\
Belonging and love needs (S6) & 0.838 \\
Safety needs (S7) & 0.831 \\
Physiological needs (S8) & 0.757 \\
\hline
\end{tabular}

all variables have a high reliability level.

The reliability test with the composite reliability can be strengthened by using the Cronbach's alpha value. A variable is reliable if it has Cronbach's alpha value of $>0.7$ [20]. Based on the data in Table VI, the value of each variable is $>0.7$. Thus, the results indicate that each variable has met the requirements for the Cronbach's alpha value, so all variables have a high level of reliability.

In inner model evaluation, the path coefficient is
TABLE V

Composite Reliability VAlues of the Variables.

\begin{tabular}{cr}
\hline Variable & Composite Reliability \\
\hline Intention to buy (R1) & 0.957 \\
Transcendence (S1) & 0.941 \\
Self-actualization (S2) & 0.931 \\
Aesthetic needs (S3) & 0.926 \\
Cognitive needs (S4) & 0.900 \\
Esteem needs (S5) & 0.929 \\
Belonging and love needs (S6) & 0.954 \\
Safety needs (S7) & 0.952 \\
Physiological needs (S8) & 0.926 \\
\hline
\end{tabular}

TABLE VI

CRONBACH's ALPHA OF THE VARIABLES

\begin{tabular}{cr}
\hline Variable & Cronbach's Alpha \\
\hline Intention to buy (R1) & 0.940 \\
Transcendence (S1) & 0.916 \\
Self-actualization (S2) & 0.901 \\
Aesthetic needs (S3) & 0.892 \\
Cognitive needs (S4) & 0.852 \\
Esteem needs (S5) & 0.898 \\
Belonging and love needs (S6) & 0.936 \\
Safety needs (S7) & 0.932 \\
Physiological needs (S8) & 0.894 \\
\hline
\end{tabular}


Cite this article as: F. Muthmainnah and F. E. Gunawan, "The Effects of the Students' Hierarchy of Needs in an Indonesian Private Academy on the Intention to Buy in Social Commerce", CommIT (Communication \& Information Technology) Journal 14(2), 81-88, 2020.

TABLE VII

PATH COEFFicient Results.

\begin{tabular}{cr}
\hline Variable & Intention to buy (R1) \\
\hline Transcendence (S1) & 0.010 \\
Self-actualization (S2) & -0.036 \\
Aesthetic needs (S3) & 0.243 \\
Cognitive needs (S4) & -0.102 \\
Esteem needs (S5) & 0.399 \\
Belonging and love needs (S6) & -0.296 \\
Safety needs (S7) & 0.681 \\
Physiological needs (S8) & -0.074 \\
\hline
\end{tabular}

TABLE VIII

MODEL FIT.

\begin{tabular}{crr}
\hline Name & Saturated Model & Estimated Model \\
\hline NFI & 0.744 & 0.744 \\
\hline
\end{tabular}

TABLE IX

R-SQUARED OF THE VARIABLE.

\begin{tabular}{cr}
\hline Variable & R-Squared \\
\hline Intention to buy (R1) & 0.632 \\
\hline
\end{tabular}

TABLE $X$

T-STATistics AND P-VALUES OF THE Hypotheses.

\begin{tabular}{lccr}
\hline Hypothesis & T-Statistics & P-Values & Result \\
\hline $\begin{array}{l}\text { H1: transcendence } \rightarrow \text { inten- } \\
\text { tion to buy }\end{array}$ & 0.123 & 0.902 & Rejected \\
$\begin{array}{l}\text { H2: self-actualization } \rightarrow \text { in- } \\
\text { tention to buy }\end{array}$ & 0.243 & 0.808 & Rejected \\
$\begin{array}{l}\text { H3: aesthetic needs } \rightarrow \text { inten- } \\
\text { tion to buy }\end{array}$ & 2.052 & 0.041 & Accepted \\
$\begin{array}{l}\text { H4: cognitive needs } \rightarrow \text { inten- } \\
\text { tion to buy }\end{array}$ & 0.793 & 0.428 & Rejected \\
$\begin{array}{l}\text { H5: esteem needs } \rightarrow \text { intention } \\
\text { to buy }\end{array}$ & 3.054 & 0.002 & Accepted \\
$\begin{array}{l}\text { H6: belonging and love needs } \\
\rightarrow \text { intention to buy }\end{array}$ & 1.988 & 0.047 & Accepted \\
$\begin{array}{l}\text { H7: safety needs } \rightarrow \text { intention } \\
\text { to buy }\end{array}$ & 6.004 & 0.000 & Accepted \\
$\begin{array}{l}\text { H8: physiological needs } \rightarrow \\
\text { intention to buy }\end{array}$ & 0.597 & 0.551 & Rejected \\
\end{tabular}

used to show how strong the effect of the independent variable is on the dependent variable. The greater the path coefficient value of the independent variable is on the dependent variable, the stronger the influence will be. The description of these results shows that half of the variables in this model have a path coefficient with a positive number. Table VII shows that the path coefficient value of transcendence, aesthetic needs, esteem needs, and safety needs has a positive value. Meanwhile, self-actualization, cognitive needs, belonging and love needs, and physiological needs have a small or negative effect on the intention to buy.

Based on data processing using the SmartPLS 3.0, the coefficient determination (R-squared) value is obtained. It is used to measure how other variables in- fluence the endogenous variable. The $\mathrm{R}$-squared result of 0.67 and above for endogenous latent variables in the structural model indicates the effect of exogenous variables on endogenous variables is in a good category. Meanwhile, if the result is $0.33-0.67$, it is in the medium category. Then, if the result is $0.19-0.33$, it is in the weak category [19].

The used approximate model fit criterion is the Bentler-Bonett index or the Normed Fit Index (NFI) [22]. The researchers follow the suggestion to use the NFI in connection with PLS path modeling based on the previous research [23]. The NFI results in values between 0 and 1 . The closer the NFI to 1 is, the better the fit will be. Based on the data presented in Table VIII, the NFI value for the research model is 0.744 . Thus, from these results, the research model has good goodness of fit of $74 \%$.

Based on the calculations, the R-squared of intention to buy is 0.632 as seen in Table IX. It means that the research model around $63 \%$ can explain the broad diversity of research data. Meanwhile, the remaining $(37 \%)$ is defined by other factors that are outside of the research model. The result is in the medium category.

After the data processing has been done, the results can be used to answer the hypothesis in the research. The hypothesis test is carried out by looking at the t-statistics value and the p-value. The research hypothesis is accepted if the p-value is $<0.05$ [24]. Table $\mathrm{X}$ presents the results of the hypothesis test in the research through the inner model.

In Table X, eight hypotheses are proposed in the research. Half of them are acceptable because of having p-values of $<0.05$. So, it can be stated that some independent variables impact the dependent variable significantly. Meanwhile, the other four hypotheses are rejected because those have p-values of $>0.05$. Hence, these four variables do not have a significant effect on the dependent variable.

The result of $\mathrm{H} 1$ shows that transcendence does not affect the intention to buy. $\mathrm{H} 1$ is rejected. Based on the finding, it can be concluded that the consumers' need to help others in purchasing on social media has not been met. It results in a decrease in the intention to buy. Therefore, existing social media must focus on features of the need to help others or share gifts so that the intention to buy on social media will increase. Similarly, $\mathrm{H} 2$ is also rejected. Selfactualization has no effect on the intention to buy. The consumers feel that their needs to develop themselves and peak experiences in buying on social media are not fulfilled. As a result, there is a decrease in their intentions to buy. Therefore, existing social media must focus on gamification features. It can create a need for consumers to experience winning experiences such 
Cite this article as: F. Muthmainnah and F. E. Gunawan, "The Effects of the Students' Hierarchy of Needs in an Indonesian Private Academy on the Intention to Buy in Social Commerce", CommIT (Communication \& Information Technology) Journal 14(2), 81-88, 2020.

as games, challenge giveaway, and others. Then, the consumers will have a high intention to buy in social media.

The results show aesthetic needs impact the intention to buy. $\mathrm{H} 3$ is accepted. Based on the finding, it can be stated that the consumers feel their need for aesthetics or the beauty of designs on their social media is met. So, their intentions to buy on social media increase. Therefore, existing social media must provide good social media design and content layout since it affects the intention to buy. In contrast, cognitive needs have no effect on the intention to buy. H4 is rejected. The consumers have not yet felt the need for an exploration experience in social commerce. In this case, it is possible that the data mining of the products on social media is not as optimal as e-commerce. Thus, it has a negative impact on brand awareness of social media itself.

Then, H5 is accepted. Esteem needs affect intention to buy. Based on the findings, it can be concluded that the consumers' need to improve their reputation and get recognition from others through purchasing on social media has been fulfilled. Thus, the intention to buy on social media increases. With features such as following, likes, shares, and comments, the intention to buy on social media can grow. Similarly, belonging and love needs influence the intention to buy. $\mathrm{H} 6$ is accepted. It implies that the consumers have felt the need for social relations between a consumer and another consumer, and between consumers and merchants has been fulfilled in social commerce. Therefore, existing social media must maintain features to help consumers connect with each other.

Moreover, safety needs have an effect on the intention to buy. $\mathrm{H} 7$ is accepted. The consumers have seen the security in purchasing on their social media so that their intentions to buy on social media increase. In this case, it is possible that many payments for purchased products on social media are cash on delivery. Thus, consumers feel safe. Account privacy features also affect consumer loyalty to continue using social media as the purchasing medium. Last, H8 is rejected. Physiological needs do not affect the intention to buy. Based on these findings, the basic needs of consumers or functional needs of social media are not met so that the buying interest in these social media decreases. In this case, social media can improve access speed, lightweight application, and quota-saving application to increase consumers' interest.

\section{CONCLUSion}

The research identifies the effects of the hierarchy of needs of students in a private academy in Indonesia on the intention to buy in social commerce. The Rsquared values show that around $63 \%$ of the research model can explain the research data. Meanwhile, the remaining $37 \%$ is explained by other factors that are outside of the used model. Based on the results, there are two main conclusions. First, transcendence, selfactualization, cognitive needs, and physiological needs do not significantly affect the intention to buy in social commerce. Second, esteem needs, safety needs, aesthetic needs, and belonging and love needs affect intention to buy. The researchers also realize that the research is far from perfect. Therefore, based on a series of discussions that have been compiled from beginning to end, there are several suggestions for further research. The future researchers can add several factors outside of the research to form a new and more comprehensive model, use different research methods and data collection methods, and compare social commerce analysis with other similar fields such as ecommerce.

\section{REFERENCES}

[1] M. Nabila. (2019) Survei APJII: Pengguna Internet di Indonesia capai 171,17 juta sepanjang 2018. [Online]. Available: https://dailysocial.id/ post/pengguna-internet-indonesia-2018

[2] R. Mahadevan. Beyond networking: Social commerce as driver of digital payments. [Online]. Available: https://www.paypalobjects.com/ digitalassets/c/website/marketing/global/stories/ images/paypal-asia-social-commerce-report.pdf

[3] N. Hajli, "Social commerce constructs and consumer's intention to buy," International Journal of Information Management, vol. 35, no. 2, pp. 183-191, 2015.

[4] E. Turban, L. Lai, and J. Strauss, Social commerce: Marketing, technology and management. London: Springer International Publishing, 2016.

[5] M. Anderson, J. Sims, J. Price, and J. Brusa, "Turning "like" to "buy" social media emerges as a commerce channel," Booz \& Company Inc, vol. 2, no. 1, pp. 102-128, 2011.

[6] N. Rahayu. (2019) Pertumbuhan e-commerce pesat di Indonesia. [Online]. Available: https://www.wartaekonomi.co.id/read216302/ pertumbuhan-e-commerce-pesat-di-indonesia. html

[7] H. Ali and L. Purwandi, Indonesia 2020: The urban middle-class millenials. Jakarta: Alvara Research Center, 2016.

[8] Sub Direktorat Statistik Rumah Tangga - Badan Pusat Statistik. (2017) Indonesia - Survei sosial ekonomi nasional 2017 Maret (KOR). [Online]. 
Cite this article as: F. Muthmainnah and F. E. Gunawan, "The Effects of the Students' Hierarchy of Needs in an Indonesian Private Academy on the Intention to Buy in Social Commerce", CommIT (Communication \& Information Technology) Journal 14(2), 81-88, 2020.

Available: https://mikrodata.bps.go.id/mikrodata/ index.php/catalog/814

[9] H. Ali, L. Purwandi, H. Nugroho, A. Ekoputri, and T. Halim, The urban middle-class millenials Indonesia: Financial and online behavior. Jakarta: PT. Alvara Strategi Indonesia, 2017.

[10] S. Jacobsen and N. G. Barnes, "On being social: How social identity impacts social commerce for the millennial shopper," International Journal of Management Science and Business Administration, vol. 3, no. 4, pp. 38-45, 2017.

[11] K. P. Lewis, P. G. Fernando Jr, M. L. C. Delos, and D. B. Gonzales, "Social commerce acceptance of students in a state university in the Philippines: A unified view," Circulation in Computer Science, vol. 3, no. 3, pp. 1-5, 2018.

[12] M. H. Abraham, "A theory of human motivation," Psychological Review, vol. 50, no. 4, pp. 370396, 1943.

[13] A. H. Maslow, Motivation and personality. New York: Harper \& Row, 1954.

[14] _ Motivation and personality. New York: Harper \& Row, 1970.

[15] - Religions, values, and peak-experiences. Viking Press, 1970.

[16] S. McLeod. (2020) Maslow's hierarchy of needs. [Online]. Available: https://www. simplypsychology.org/maslow.html

[17] N. K. Malhotra, Marketing research: An applied orientation. Prentice-Hall International, 2004.

[18] J. F. Hair Jr, G. T. M. Hult, C. Ringle, and M. Sarstedt, A primer on Partial Least Squares Structural Equation Modeling (PLSSEM). Thousand Oaks: SAGE publications, 2017.

[19] W. W. Chin, "The Partial Least Squares approach to Structural Equation Modeling," Modern Methods for Business Research, vol. 295, no. 2, pp. 295-336, 1998.

[20] I. Ghozali, Structural Equation Modeling metode alternatif dengan Partial Least Squares (PLS). Semarang: Badan Penerbit Universitas Diponegoro, 2014.

[21] A. M. Hubley, Discriminant validity, ser. Encyclopedia of quality of life and well-being research. London: Springer Science+Business Media Dordrecht, 2014, pp. 1664-1667.

[22] P. M. Bentler and D. G. Bonett, "Significance tests and goodness of fit in the analysis of covariance structures." Psychological Bulletin, vol. 88, no. 3, pp. 588- 606, 1980.

[23] J. B. Lohmöller, Latent variable path modeling with Partial Least Squares. Physica-Verlag
Heidelberg, 1989

[24] S. Yamin and H. Kurniawan, Generasi baru mengolah data penelitian dengan Partial Least Square path modeling. Jakarta: Salemba Infotek, 2011. 